\title{
ENERGY CLUSTERS AS TOOL IN PURSUIT OF ENERGY SELF-SUFFICIENCY IN SELECTED RURAL AREA OF POLAND
}

\author{
Karol Tucki, Leszek Mieszkalski, Krzysztof Kulpa \\ Warsaw University of Life Sciences, Poland \\ karol_tucki@sggw.pl, leszek_mieszkalski@sggw.pl
}

\begin{abstract}
The manuscript presents an analysis of the energy potential of the selected five rural municipalities in pursuit of their energy self-sufficiency by building a common Energy Cluster. The case study was the planned investment in the Energy Cluster, which will be based exclusively on renewable energy sources. The investment will be located in the central part of Poland. For the analyzed investment, an energy balance was made, in which the level of production from renewable energy sources was assumed to be $60 \%$ of total electricity demand. In addition, the number of cluster participants was assumed to be $50 \%$ of all inhabitants of communes in the area of the cluster. For the purposes of the balance sheet, the assumed average annual consumption values for specific customer groups were used. The investment cost was simplified with the assumed level of co-financing of $70 \%$. In order to achieve the objectives set out in the balance sheet with the assumed level of co-financing, it is necessary to allocate over PLN 13.5 million in a long-term perspective. Moreover, the manuscript presents the results of a survey conducted among the inhabitants of the communes where the Energy Cluster will be built. The survey was attended by 46 residents of the analyzed area.The aim of this study was to determine the level of knowledge of the inhabitants of the communes about the planned investment and to examine their willingness to participate in it. In the opinion of the respondents, the greatest benefit for which they would express their willingness to participate in the planned investment would be the reduction of the final price of electricity. Most of the respondents declare that their house or apartment is after the thermal renovation process and is fired by a solid fuel furnace(over $60 \%$ ).
\end{abstract}

Keywords: energy, cluster, investment, rural.

\section{Introduction}

Poland consumes approx. 170 TWh of electricity per year. This demand is mainly satisfied by domestic power plants. Hard coal and lignite still remain the chief raw materials used to produce electricity although their share in Poland's energy mix has been decreasing for many years [1]. The Polish economy is slowly heading towards renewable energy sources (RES) [2]. International obligations have a significant impact on this process and global trends and economic development are reasons for constant changes in the sector [3]. The climate and energy policy of the European Union also has a big impact on these changes [4]. In 2009, a regulation package was adopted which set out three main objectives for combating climate change by 2020 (the so-called "3 x $20 \%$ Package"). Poland was obliged, among others, to increase its RES energy production up to $15 \%$ in the total final energy consumption. Then, in 2018, after revising its 2014 targets, Poland was obliged to achieve at least a $32 \%$ share of renewable energy sources in its gross final energy consumption by 2030. Potential penalties or the necessity to buy renewable energy from abroad motivate the country's authorities to develop renewable energy [5]. Air pollution is yet another factor that calls for action in this direction. One of the kinds of mechanisms that stabilise the share of renewable energy sources (RES) in the Polish energy system are energy clusters [6].

The Energy Cluster is a new concept in the Polish legal system, in which the dominant energy infrastructure model was historically understood as strictly centralised, with hardly any involvement of citizens in energy production [7]. The clusters are a tool to support the development of distributed energy. They are to implement the aforementioned goal with regard for the environment [8]. They are to create optimal legal, organizational and financial conditions that would enable the introduction of the latest technologies, with regard for the local resources and the potential of the national energy industry [9]. The expected results (or goals) of cluster activities include: improvement of air and water quality; improvement of the quality of energy supply, local energy security with the use of the local resources; development of entrepreneurship using the local potential [10].

Renewable energy cooperatives are intended to enable citizens to collectively own and manage renewable energy projects at the local level. From an economic point of view, cooperatives present a differentownership model than conventional business organizations [11]. Unlike capitalist corporations, they are owned by their members - users, not investors. In addition, net earnings are usually divided proportionally between members - not according to their shares - but according to the 
volume of transactions they made with a customer company [12]. Moreover, when part of the net profit is allocated as a return on equity, such distribution of profits is subject to a limit, which means that maximizing return on capital cannot be the key goal. Lastly, they present a democratic governance structure that includes equal individual voting rights and no entry barriers for new members [13].

The Energy Cluster is a civil law agreement of local entities involved in the production, consumption, storage and sale of electricity, heat, cold, electricity in transport as well as fuels. The cluster itself, as it is initiated in the form of a civil law agreement, is not subject to registration in any system [14]. It should be emphasized that clusters are quite a new creation in the Polish legal system. The concept of a cluster is flexible enough to enable building a customised business model of the cluster's operation. This makes it possible to select the optimal legal form of its business operation. It could be, e.g. a region of five boroughs or an entire county (poviat), a cooperative established specially for this purpose, or many other legal forms. Participation in a cluster does not necessarily mean the cessation of current operations. Quite the opposite - a cluster can associate many local entities, which, when cooperating, can generate added value for all the other cluster members. The concentration of many entities in one common cause can provide a greater source of financing and better organisational facilities. It can also provide better pricing due to the larger scale of investment compared to individual investment. The adopted form of cluster functioning seems to be a good direction in the development of distributed energy in Poland [15]. The aggregation of entities with the same goals can contribute to obtaining a better result. Probably one of the first barriers to overcome for pilot energy clusters in Poland is likely to be the necessity to promote this idea and reach those entities in the area which are potentially willing to act. Energy Clusters are also included in the Polish Energy Policy until 2040 project.

\section{Materials and methods}

The subject of the analysis is the energy cluster located in Mazowieckie Province (central part of Poland). The analyzed Cluster covers the area of five neighbouring boroughs. The total area of the boroughs included in the cluster is $604.7 \mathrm{~km} 2$. The starting point for the analysis of energy selfsufficiency of the rural area in question were demographic data (population, area, population density in all five communes of the Cluster), natural conditions specific to the analysed area and the current method of supplying the boroughs with electricity.

Based on the analysis, it was found that the natural conditions do not interfere with the current form of the cluster, nor they appear to block the implementation of the Cluster's tasks and its future development. The electricity distribution network in the analyzed boroughs is able to meet the cluster's goals.

The average calculated energy consumption per person in the cluster is $0.8 \mathrm{MWh}$ per person. The total electricity consumption is $44228.41 \mathrm{MWh}$.

Based on the above information, specific customer groups and their average annual demand for electricity were assumed in order to balance their demand for electricity. Approximate demand and simplified investment costs were calculated. In addition, a survey was conducted to examine the level of knowledge about the investment among the residents of the area covered by the energy cluster.

\section{Results and discussion}

To prepare the balance sheet, data were obtained on the number of individual groups of electricity consumers from the entire Cluster. The number of Cluster participants was assumed at the level of $50 \%$ of recipients (Figure 1).

As of 02.10 .2017 , the capacity installed from renewable energy sources in the Cluster was 10 MW. It was a RES installation on some public buildings. The consumer demand for electricity, with regard to customer types, is presented in Table 1.

The simultaneity coefficient (ratio of the peak main power line and the sum of peak branch power lines) was assumed for specific groups of recipients: household $85 \%$, farm $90 \%$, enterprises $90 \%$, public buildings $90 \%$. The demand for electricity with regard to the abovementioned factor and assuming the $60 \%$ renewable energy production target is presented in Table 2 . 


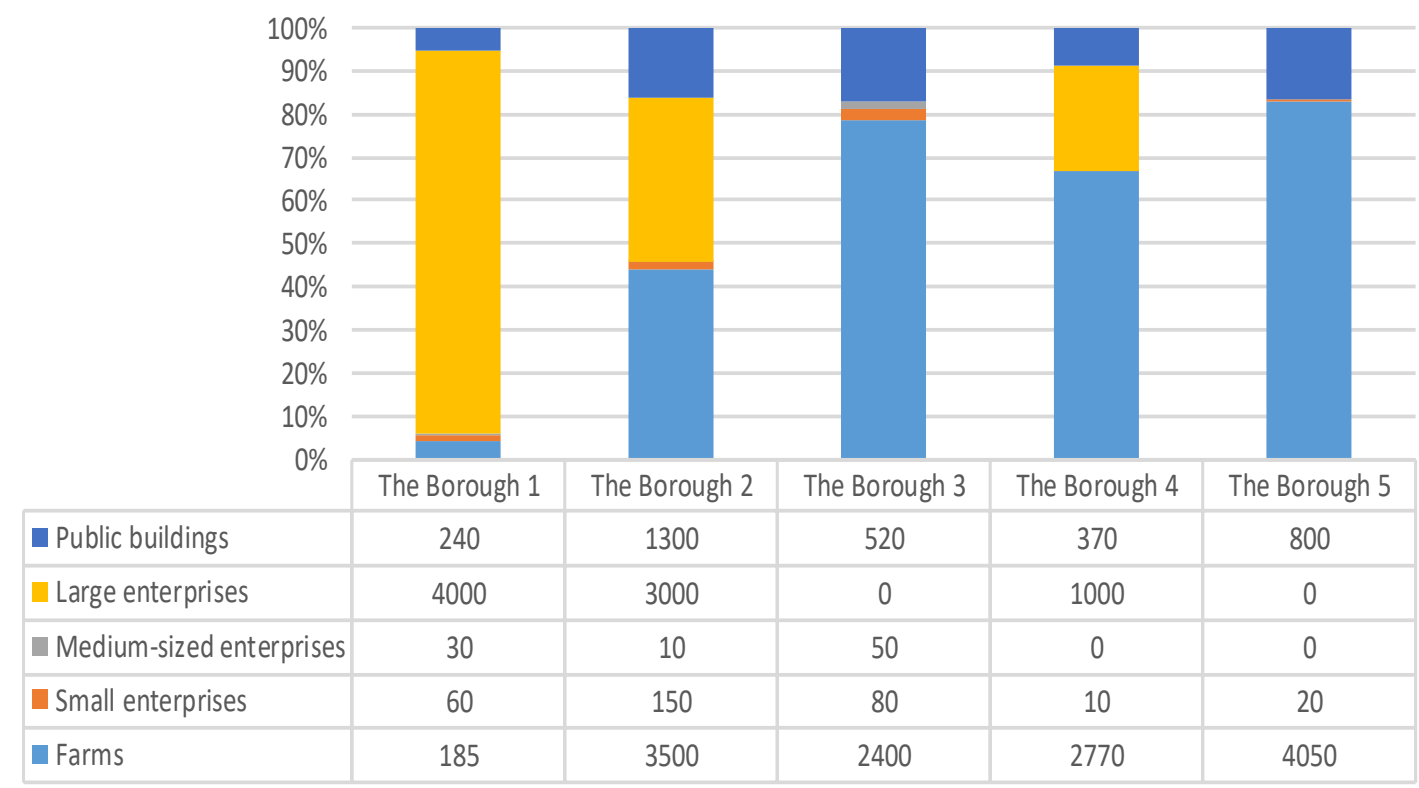

Fig. 1. Energy demand by municipalities, MWh

Total electricity demand after considering existing energy sources in the Cluster

\begin{tabular}{|c|c|}
\hline Type of recipient & Energy demand, MWh \\
\hline Households & 15149.75 \\
\hline Farms & 7244.00 \\
\hline Enterprises & 155.00 \\
\hline Public buildings & 40.20 \\
\hline Total & 22588.95 \\
\hline
\end{tabular}

Table 2

Demand for electricity with regard to the simultaneitycoefficient and assuming a $60 \%$ target for the production of energy from RES

\begin{tabular}{|c|c|c|}
\hline Type of recipient & $\begin{array}{c}\text { Cluster electricity demand. } \\
\text { VS, } \mathbf{k W h} \text { (simultaneity } \\
\text { coefficient) }\end{array}$ & $\begin{array}{c}\text { Set goal to achieve } \\
\text { electricity production from } \\
\text { RES - 60 \%, } \mathbf{k W h}\end{array}$ \\
\hline Households & 12877287.50 & 7726373 \\
\hline Farms & 6519600.00 & 3911760 \\
\hline Enterprises & 139500.00 & 83700 \\
\hline Public buildings & 36180.00 & 21708 \\
\hline Total & 19572567.50 & 11743541 \\
\hline
\end{tabular}

The necessary installed capacity to ensure the assumed demand values is $10.2 \mathrm{MW}$. To cover the respective needs, the required amounts are: $6.7 \mathrm{~kW}$ for households, $3.4 \mathrm{MW}$ for farms, $0.08 \mathrm{MW}$ for enterprises, and $0.02 \mathrm{MW}$ for public buildings. It was assumed that prosumer installations would be found on households, farms and public buildings. The so-called "large" RES production is to concern enterprises. The planned biogas plant is to achieve an installed capacity of $1.7 \mathrm{MW}$. The proportion of production according to demand is presented in Table 3. The total cost was estimated at 45156276.88 PLN with the installed capacity of 10.1 MW. External co-financing of $70 \%$ was assumed, the projected cost after including the co-financing is 13546883 PLN.

The survey consisted of 9 questions (Table 4). The respondents gained access to the survey through a special website leading directly to the survey. The survey was conducted among a small number of recipients (46), compared to all residents within the Cluster. An analysis of the entire crosssection of the society living in the Cluster could provide a more comprehensive picture. Although only half of the respondents had heard about the existence of the Energy Cluster before, most of the 
respondents would be interested in participating in the cluster if it were to bring positive effects for them in the future: RES subsidies, electricity price reduction.

Table 3

Productionproportion vs demand - goals set for the construction of renewableenergysources

\begin{tabular}{|c|c|c|c|c|}
\hline $\begin{array}{c}\text { Cluster } \\
\text { participant }\end{array}$ & $\begin{array}{c}\text { Installation } \\
\text { type }\end{array}$ & $\begin{array}{c}\text { Planned capacity to } \\
\text { be installed, MW }\end{array}$ & $\begin{array}{c}\text { Construction } \\
\text { cost 1 kW gross, } \\
\text { PLN }\end{array}$ & $\begin{array}{c}\text { Construction } \\
\text { cost - total, PLN }\end{array}$ \\
\hline Households & $\begin{array}{c}\text { prosumer } \\
\text { installations }\end{array}$ & 3.4 & 4500.00 & 15126735.26 \\
\hline Farms & $\begin{array}{c}\text { prosumer } \\
\text { installations }\end{array}$ & 1.7 & 4500.00 & 7563367.63 \\
\hline Enterprises & $\begin{array}{c}\text { "large" RES } \\
\text { production }\end{array}$ & 2.5 & 4000.00 & 10084490.17 \\
\hline Public buildings & $\begin{array}{c}\text { prosumer } \\
\text { installations }\end{array}$ & 0.8 & 4500.00 & 3781683.81 \\
\hline Biogas plant & $\begin{array}{c}\text { "large" RES } \\
\text { production }\end{array}$ & 1.72 & 5000.00 & 8600000.00 \\
\hline - & Total & 11.9 & - & 45156276.88 \\
\hline
\end{tabular}

According to the respondents, the most important benefit is the reduction in the price of electricity. It would also be important to ensure the stability of electricity supply. The next important issue was the reduction of the so-called "low emissions". Lastly, there was the raising of ecological awareness in the inhabitants and the development of local enterprises. Over half of those surveyed declared that they intended to invest in renewable energy within the next 10 years. The overwhelming majority of respondents stated that their home was already subject to thermal renovation. The vast majority of the respondents (over $60 \%$ ) declare that their home is heated with a solid fuel boiler.

Table 4

Description of the data obtained from the survey

\begin{tabular}{|c|c|c|c|c|c|}
\hline Variable Name & Response options & Average & $\begin{array}{l}\text { Standard } \\
\text { Deviation }\end{array}$ & Min. & Max. \\
\hline Gender & $1=\operatorname{man} ; 0=$ woman & 0.46 & 0.5 & 0 & 1 \\
\hline Age & In years & 44.36 & 11.25 & 21 & 67 \\
\hline Education & $1=$ college $; 0=$ other & 0.74 & 0.32 & 0 & 1 \\
\hline Marital Status & $1=$ married $; 0=$ other & 0.83 & 0.37 & 0 & 1 \\
\hline $\begin{array}{l}\text { Are you a resident of } \\
\text { one of the five } \\
\text { boroughsfrom the } \\
\text { Energy Cluster area? }\end{array}$ & $1=$ yes $; 0=$ no & 0.78 & 0.34 & 0 & 1 \\
\hline $\begin{array}{l}\text { Have you heard of the } \\
\text { existence of the Energy } \\
\text { Cluster? }\end{array}$ & $1=$ yes $; 0=$ no & 0.52 & 0.50 & 0 & 1 \\
\hline $\begin{array}{c}\text { Do you have } \\
\text { knowledge in the field } \\
\text { of energy clusters in } \\
\text { Poland? }\end{array}$ & $\begin{array}{l}\text { 1 - I do not know what energy } \\
\text { clusters are; } 2 \text { - I have heard about } \\
\text { energy clusters, but I do not know } \\
\text { what they are; } 3 \text { - I have heard } \\
\text { about energy clusters, I know some } \\
\text { basic information about clusters; } 4 \\
\text { - I know what energy clusters are } \\
\text { and how they work; } 5 \text { - I am a } \\
\text { person with comprehensive } \\
\text { knowledge of energy clusters. }\end{array}$ & 2.48 & 0.76 & 1 & 5 \\
\hline
\end{tabular}


Table 4 (continued)

\begin{tabular}{|c|c|c|c|c|c|}
\hline Variable Name & Response options & Average & $\begin{array}{l}\text { Standard } \\
\text { Deviation }\end{array}$ & Min. & Max. \\
\hline \multirow{6}{*}{$\begin{array}{l}\text { Please specify in } \% \\
\text { what would be the } \\
\text { most important for you } \\
\text { among the benefits of } \\
\text { participating in the } \\
\text { cluster? (in total they } \\
\text { should amount to } \\
100 \% \text { ) }\end{array}$} & \multicolumn{5}{|c|}{ weight in $\%($ total $100 \%)$} \\
\hline & 1. Reduction of electricity costs & 54.17 & 18.80 & 0 & 100 \\
\hline & $\begin{array}{l}\text { 2. Stability of energy supply (lower } \\
\text { risk of power failure) }\end{array}$ & 17.78 & 20.12 & 0 & 100 \\
\hline & 3. Development of local enterprises & 6.39 & 8.67 & 0 & 30 \\
\hline & $\begin{array}{l}\text { 4. Reduction of the so-called 'low } \\
\text { emissions' (which pose a threat to } \\
\text { the health and life of residents) }\end{array}$ & 13.33 & 10.37 & 0 & 55 \\
\hline & $\begin{array}{l}\text { 5. Raising the ecological awareness } \\
\text { in the inhabitants }\end{array}$ & 8.33 & 8.70 & 0 & 50 \\
\hline $\begin{array}{l}\text { Do you plan to invest } \\
\text { in RES in the future } \\
\text { (up to } 10 \text { years)? } \\
\text { (Renewable Energy } \\
\text { Sources - e.g. } \\
\text { photovoltaic panels, } \\
\text { heat pumps) }\end{array}$ & $\begin{array}{l}1=\mathrm{I} \text { already have such an } \\
\text { installation/the installation is under } \\
\text { design or construction; } 0.5=\mathrm{I} \text { have } \\
\text { not made such decisions yet; } 0=\mathrm{I} \\
\text { am not interested in investing in } \\
\text { renewable energy }\end{array}$ & 0.57 & 0.12 & 0 & 1 \\
\hline $\begin{array}{l}\text { Has your house/flat } \\
\text { been subject to thermal } \\
\text { renovation? (insulation } \\
\text { of external walls, } \\
\text { replacement of } \\
\text { windows and doors) }\end{array}$ & $1=$ yes $; 0=$ no & 0.87 & 0.23 & 0 & 1 \\
\hline $\begin{array}{l}\text { Would you be } \\
\text { interested in } \\
\text { participating in a } \\
\text { cluster in order to } \\
\text { obtain potential } \\
\text { funding for a RES } \\
\text { installation? }\end{array}$ & $1=$ yes $; 0.5=$ do not know; $0=$ no & 0.80 & 0.27 & 0 & 1 \\
\hline $\begin{array}{l}\text { Would you be } \\
\text { interested in } \\
\text { participating in the } \\
\text { Cluster, if it might } \\
\text { result in a future lower } \\
\text { price for electricity or } \\
\text { heating? }\end{array}$ & $1=$ yes $; 0.5=$ do not know; $0=$ no & 0.91 & 0.15 & 0 & 1 \\
\hline
\end{tabular}

When analysing the answers of the respondents, it should be remembered that the respondents were inhabitants of rural areas with different levels of wealth and education. This may undoubtedly affect the attitude of the respondents to environmental protection and to the energy investment under analysis. The most optimistic answer to the survey is the fact that the vast majority of respondents have heard about energy clusters in Poland and have basic information about clusters (average 2.48, standard deviation 0.76 ). In addition, the vast majority of the respondents live in thermorenovated houses/apartments (mean 0.87, standard deviation 0.23) and have not yet decided whether to invest in renewable energy sources within 10 years (mean 0.57 , standard deviation 0.12 ).

\section{Conclusions}

The argument of the pursuit for energy self-sufficiency in selected rural areas remains open. It takes a number of analysis and cooperation, not only at the local level, to develop models that will allow them to be referred to in the future. Based on the manuscript, it can be stated that: 
1. In order to achieve the goals assumed in the balance sheet together with the assumed level of cofinancing, it is necessary to allocate over PLN 13.5 million in the long-term perspective. The production of electricity will amount to $11,743,540.5 \mathrm{kWh}$, the installed capacity of photovoltaic devices will be $10.1 \mathrm{MW}$, and biogas plants - $1.72 \mathrm{MW}$.

2. The case analyzed in the manuscript assumed $50 \%$ of cluster participants and their energy demand for RES energy covered at $60 \%$. Despite this, the cost was over PLN 13.5 million, even with external financing assumed. A comprehensive financial analysis of such an undertaking should have to be carried out. Possible ways of external financing and the internal possibilities of the investors should be considered.

3. Most of the respondents live in the area of the Cluster, have higher education and are married. About half of the respondents have heard about the existence of the Energy Cluster. The general knowledge about clusters in the respondents is defined as average. For the respondents, the main goal for the cluster and the reason they would like to participate would be a reduction in the final price of electricity. Most respondents declare that their house/flat is after thermal renovation and is heated with a solid fuel stove.

4. The results of the survey show that inhabitants of rural areas do not exclude investments in renewable energy installations in the future.

\section{References}

[1] Tucki K., Orynycz O., Wasiak A., Swic A., Dybas W. Capacity market implementation in Poland: analysis of a survey on consequences for the electricity market and for energy management. Energies, vol. 12, 2019, pp. 1-16.

[2] Manowska A., Tobór-Osadnik K., Wyganowska M. Economic and social aspects of restructuring Polish coal mining: Focusing on Poland and the EU. Resour. Policy, vol. 52, 2017, pp. 192-200.

[3] Wierzbowski M., Filipiak I., Lyzwa W. Polish energy policy 2050—An instrument to develop a diversified and sustainable electricity generation mix in coal-based energy system. Renew. Sustain. Energy Rev., vol. 74, 2017, pp. 51-70.

[4] Gawlik L., Szurlej A., Wyrwa A. The impact of the long-term EU target for renewables on the structure of electricity production in Poland. Energy, vol. 92, 2015, pp. 172-178.

[5] Paska J., Sałek M., Surma T. Current status and perspectives of renewable energy sources in Poland. Renew. Sustain. Energy Rev., vol. 13, 2009, pp. 142-154.

[6] Hernik J., Noszczyk T., Rutkowska A. Towards a better understanding of the variables that influence renewable energy sources in eastern Poland. Journal of Cleaner Production, vol. 241, 2019, pp. 115-125.

[7] Grešlová P., Štych P., Salata T., Hernik J., Knížková I., Bič́́k I., Jeleček L., Prus B., Noszczyk T. Agroecosystem energy metabolism in Czechia and Poland in the two decades after the fall of communism: From a centrally planned system to market oriented mode of production. Land Use Policy, Vol. 82, 2019, pp. 807-820.

[8] KlastryEnergii (Energy Clusters). [online] [24.03.2020]. Available at: https://www.gov.pl/web/aktywa-panstwowe/klastry-energii(In Polish).

[9] Klastryenergii - nowypoczątek (Energy clusters - a new beginning). [online] [29.03.2020]. Available at: https://www.cire.pl/item,166176,13,0,0,0,0,0,klastry-energii---nowy-poczatek.html (In Polish).

[10] Lowitzsch J., Hoicka C.E., Van Tulder F.J. Renewable energy communities under the 2019 European Clean Energy Package - Governance model for the energy clusters of the future? Renewable and Sustainable Energy Reviews, vol. 122, 2020, pp. 1-13.

[11] First energy cluster in Poland with participation of SUNfarming. [online] [24.03.2020]. Available at: https://sunfarming.de/en/blog/first-energy-cluster-in-poland-with-participation-of-sunfarming.

[12] Regional clusters in energy planning (REGCEP). [online] [24.03.2020]. Available at: https://ec.europa.eu/energy/intelligent/projects/en/projects/regcep.

[13] Inês C., Guilherme P.L., Esther M.G., Swantje G., Stephen H., Lars H. Regulatory challenges and opportunities for collective renewable energy prosumers in the EU. Energy Policy, vol. 138, 2020, pp. 1-11. 
[14] Stimulation of regional RES HEAT markets through establishment of regional SME clusters (Green Energy Clusters) (GREEN ENERGY CLUSTER). [online] [24.03.2020]. Available at: https://ec.europa.eu/energy/intelligent/projects/en/projects/green-energy-cluster.

[15] Gronkowska, J. Model energy cluster - special energy zone delivering integrated territorial energy. Geomatics, Landmanagement and Landscape, vol. 3, 2017, pp. 47-57. 